\title{
Hearstův hrad. Kalifornský sen v záři evropské umělecké tradice
}

\section{The Hearst Castle. California Dream in the Glow of European Artistic Tradition}

Abstract: Hearst Castle is one of the world's most famous public museums. Its architect Julia Morgan built the magnificent building near San Simeon on the Pacific Coast in Central California for William Randolph Hearst between 1919-1947. Its architectural form is mostly based on the examples of the Mediterranean architecture of Spain and southern Italy. The private residence where Hearst had hosted the famous Hollywood Society became a public cultural heritage in 1957. Since then, visitors have been allowed to admire Casa Grande and other suites, furnished with an unusually rich collection of European works of art, mostly of Medieval and Renaissance origins. The interiors are preserved in the original state in order for the visitors to enjoy the atmosphere of the 1930s. The installation of the artworks is one of the prime examples of the living history approach in a museum.

Keywords: Hearst Castle, California, William Randolph Hearst, Julia Morgan, Art Collection, Gothic and Renaissance style, European tradition, Museum

Základy amerických muzejních a galerijních sbírek byly položeny a výrazně rozvíjeny v období tzv. Zlatého věku. Finanční magnáti John Pierpont Morgan, Henry Clay Frick, Andrew Carnegie, John D. Rockefeller Jr. nebo Isabella Stewart Gardner aj. investovali profity ze své podnikatelské činnosti $\mathrm{v}$ nemalé míře do nákupu uměleckých děl. Postupně vybudovali bohaté umělecké sbírky, jejichž prestiž zajištovala především díla evropské provenience. Své sbírky prezentovali nejprve ve svých soukromých rezidencích, z nichž některé byly následně proměněny ve veřejné instituce. Řadou uměleckých předmětů ze svých sbírek obohatili rovněž nově založená veřejná muzea a galerie budované v centrech východního pobřeží Spojených států. K těmto renomovaným, a pro Evropany jistě známějším institucím, je nutno přičíst jedno z nejvýznamnějších, dnes opět veřejných muzeí umění, situované na pobřeží Tichého oceánu - tzv. Hearstův hrad v Kalifornii. Jeho stavebník William Randolph Hearst (1863-1951), věhlasný zakladatel novinového impéria, vynaložil enormní množství finančních prostředků na vybudování řady svých sídel, které průběžně vybavoval historickým nábytkem a cennými uměleckými díly. $\mathrm{K}$ jeho nejproslulejším rezidencím, zrcadlícím evropskou uměleckou tradici, patří hrad v blízkosti San Simeon. Pưvodně soukromé sídlo vybavené řadou uměleckých předmětů se koncem 50. let 20. století proměnilo $\mathrm{v}$ jedno $\mathrm{z}$ nejprestižnějších veřejných muzeí umění nejen v Kalifornii, ale ve Spojených státech vůbec. Z hlediska architektonického řešení a interiérového vybavení tento "kalifornský div“" plně zapadá do evropského kontextu, týkajícího se jak uměleckého trhu, tak procesu přeměny soukromých sbírek ve veřejné instituce a jejich podoby na konci 19. a na počátku 20. století.

\section{Hearstův hrad jako veřejné muzeum}

Když v roce 1927 Hearst prohlásil: „Nevidím jediný dưvod, proč by ranč neměl být muzeem nejlepších věcí, které mohu získat," "1 předurčil

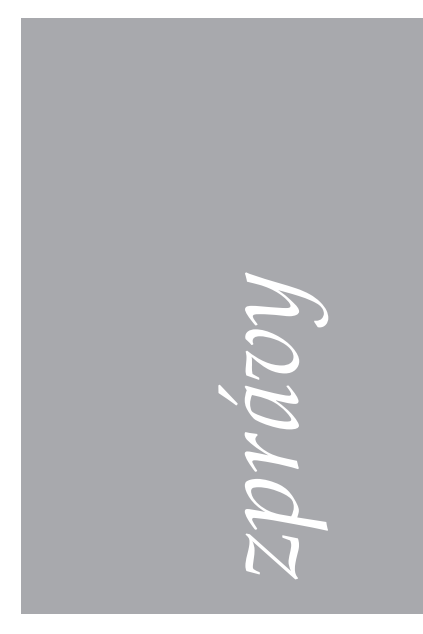

1 PROCTER, Ben. William Randolph Hearst. Final Edition, 1911-1951. Oxford: Oxford University Press, 2007, s. 146.

PhDr. Markéta Jarošová, PhD. Ústav dějin křestanského umění

Katolická teologická fakulta Univerzita Karlova 
2 Hearst San Simeon State Historical Monument. In: BROWN, Thomas. The Illustrated History of Hearst Castle. Atascadero: Nouveaux Press, 2016, s. 117.

3 Zhlédli řadu středověkých hradů v Británii, spatřili benediktinské opatství Mont-SaintMichel v Normandii nebo bavorský zámek Neuschwanstein, objekty, které svým situováním a "pohádkovou" atmosférou malému Hearstovi utkvěly výrazně v paměti. Uchvátily je i další památky v Itálii, zejména $v$ Benátkách.

$4 \mathrm{~V}$ dopise adresovaném Georgi Hearstovi Phoebe poznamenala: „Bylo těžké presvědčit malého Willyho, že nemůžeme koupit všechno, co jsme viděli." Traduje se anekdota, kdy William, po zhlédnutí umělecké sbírky v Louvru prosil, aby ji matka celou zakoupila. Williamova vášeň pro umění se stala doslova "mánii", což následně doznávala i jeho žena Millicent. In: PROCTER, Ben. William Randolph Hearst. Final Edition, 1911-1951. Oxford: Oxford University Press, 2007, s. 32. 5 Evropu navštěvoval pravidelně. Kromě metropolí jako Londýn nebo Pařiž často podstupoval léčebnou kúru v Bad Nauheim nedaleko Frankfurtu nad Mohanem. Ibidem, 6.

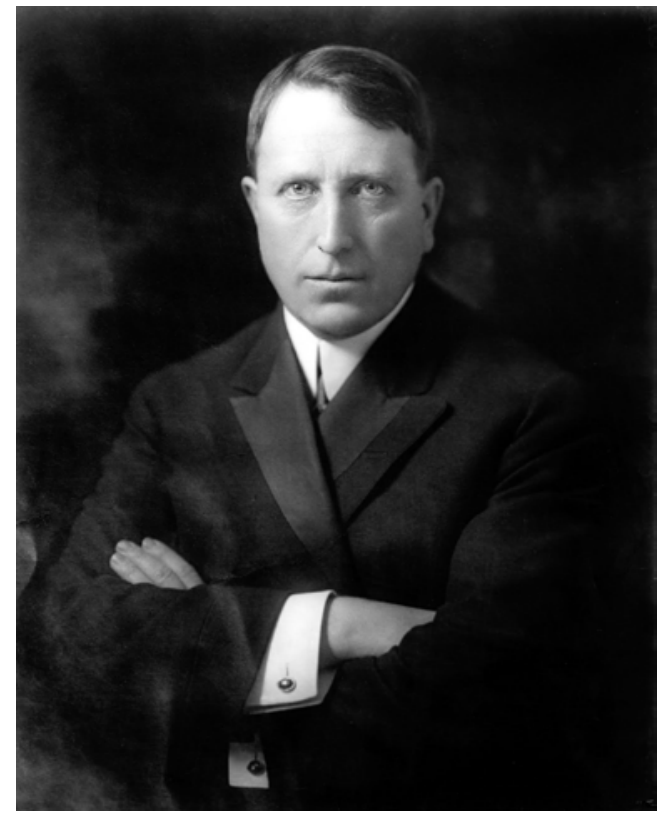

William Randolph Hearst (1863-1951), zdroj: https://commons.wikimedia.org/wiki/ File:WilliamRandolphHearst.jpg

de facto účel, roli a budoucnost své rezidence. Po jeho smrti (†1951) společnost Hearst Corporation nabídla roku 1957 toto sídlo, včetně uměleckých děl tvořících nedílnou součást interiérového vybavení, jako historickou památku do správy Státního parku Kalifornie. Tento akt byl v ideové rovině chápán jako Hearstův dar kalifornskému lidu a rezidence se současně stala národní kulturní památkou. ${ }^{2}$

Komnaty Hearstova paláce byly $\mathrm{v}$ doprovodu průvodce veřejnosti poprvé zpř́ístupněny při slavnostním otevření dne 2. června 1958 a u návštěvníků vzbudily ohromný ohlas. Transformací soukromé rezidence na veřejné muzeum totiž nedošlo $\mathrm{k}$ výraznějším architektonickým zásahům ani ke změnám $\mathrm{v}$ podobě interiérového vybavení, a tak "muzeum" i nadále vypadalo jako „soukromá rezidence“. Umělecká sbírka se po Hearstově smrti akvizičně dále nerozvíjela, v podstatě zůstala "zakonzervovaná" v čase a dodnes více než $90 \%$ uměleckých předmětů bylo zakoupeno Hearstem výhradně pro toto panství. Výstavní koncept založený na principu tzv. živé historie, jejímž cílem je v tomto př́ípadě zpřítomnit návštěvníkům atmosféru sídla 30. let a připomenout jeho sociokulturní kontext, byl doplněn řadou doprovodných průvodcovských programů, včetně atraktivních nočních prohlídek. I nadále je při výkladech pozornost zaměřena především na postavu a životní styl Williama Randolpha Hearsta, jeho rodinu a hosty, kteří rezidenci hojně navštěvovali. Na pozadí dějinných událostí je pak interpretována umělecká sbírka, architektonické řešení stavebního komplexu, zahrnujícího reprezentativní místnosti, soukromé pokoje hlavní budovy i prohlídky apartmánů určených pro hosty, kuchyně i venkovní zahrady. V roce 2001 získal Hearstův hrad vysoce prestižní akreditaci Americké aliance muzeí, podle které splňuje nejvyšší profesionální požadavky kladené na muzejní instituce a řadí jej tak mezi elitní muzea ve Spojených státech. Od počátku své existence se muzeum kontinuálně snaží zachovávat a interpretovat architektonickou podobu i umělecké sbírky a nadále rozvíjet doprovodné průvodcovské a výukové programy. Hearstův hrad je chápán jako nenahraditelná součást kulturního a historického dědictví amerického národa, které je zapotřebí uchovat i pro budoucí generace. Návštěvníkům přijíždějícím si prohlédnout tuto památku se skýtá unikátní „prožitek kalifornského snu“ vybudovaný na "kouzelné hoře“ v zrcadle evropské umělecké tradice.

\section{Kalifornské kořeny a evropská inspirace}

Proč si za své nejvelkolepější sídlo Hearst zvolil právě lokalitu v blízkosti zátoky San Simenon na pobřeží Tichého oceánu? Pozemky, na kterých se rozprostírá ikonický hrad, zdědil po svém otci Georgi Hearstovi (†1891). Ten zbohatl díky důlní činnosti a svůj zisk $z$ těžby investoval do nákupu půdy. V roce 1865 získal pozemky Rancho Piedra Blanca, následně zakoupil sousední Rancho San Simeon a Rancho Santa Rosa. Ranče, které získal po otci, Hearst rozšíríil o další pozemky 
o rozloze přibližně 250000 akrů. Půda a finanční prostředky získané po otci, a také vzdělání a sběratelská vášeň zděděná po matce, vytvořily materiální i ideový základ pro Hearstovu realizaci „fantaskního hradu“ vybudovaného na „kouzelném vrchu“. "Pohádkovou“ podobu zámku a jeho situování na kopci bezpochyby podnítila řada architektonických památek, které spatřil $\mathrm{v}$ Evropě. Uvádí se, že Hearsta výrazně ovlivnila již první evropská cesta, kterou podnikl ve svých deseti letech společně se svou matkou Phoebe Apperson Hearstovou roku 1873. Phoebe Hearstová, povoláním učitelka, usilovala o to, aby její jediný syn získal patřičné vzdělání. Součástí dobré výuky bylo poznat evropskou kulturu, seznámit se s historií, a především s uměleckými památkami prostřednictvím Grand Tour. William s matkou navštívili několik evropských zemí včetně Britských ostrovů, Francie, Německa a Itálie, kde zhlédli řadu významných architektonických památek, včetně hradů a zámků, a navštívili nejslavnější veřejné i privátní umělecké sbírky ${ }^{3}$ a v prủběhu cesty současně nakupovali drobné umělecké předměty. ${ }^{4}$ Role, jakou sehrála matka, byla bezpochyby zásadní pro rozvoj Hearstova vztahu k uměleckým předmětům a sběratelství vưbec. Od svých třiceti let intenzivně cestoval do Evropy, ${ }^{5}$ procházel aukční katalogy a sbíral umělecké předměty, do nichž investoval nemalé finanční prostředky.

Velkolepé plány na výstavbu snového zámku spřádal Hearst ve svých představách zřejmě již od dětství, avšak s jeho realizací započal až ve svých šestapadesáti letech. Svým vizionářským projektem pověřil architektku Julii Morganovu ze San Francisca, která dř́ve pracovala na realizaci přestavby rezidence Hacienda del Pozo de Verona, kterou vlastnila Phoebe Hearstová v kalifornském Pleasantonu, a řadě dalších zakázek. ${ }^{6}$ Hearstův hrad je však nejproslulejší stavební realizací, na které se Morganová podílela. Na projektu začala pracovat od roku 1919, prričemž hlavní stavební fáze probíhaly $\mathrm{v}$ průběhu 20 . až 30. let

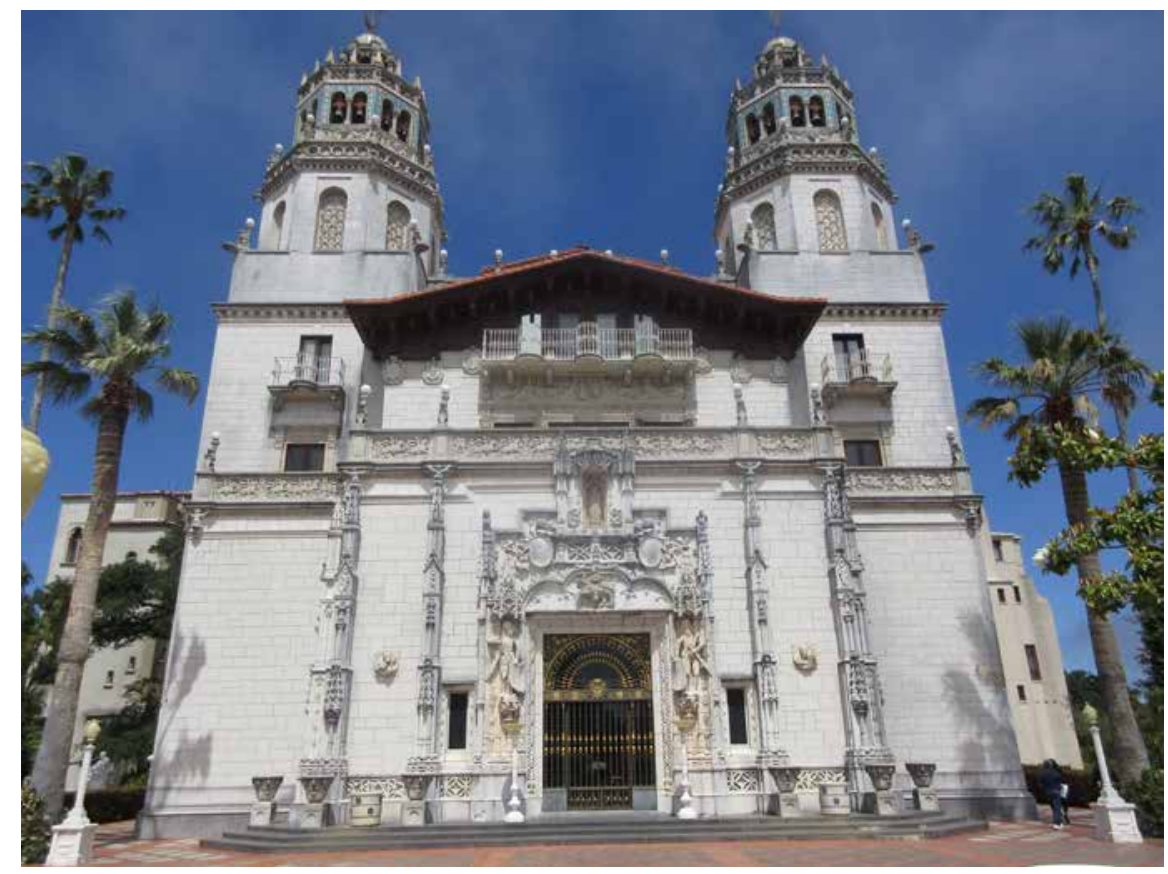

20. století a pokračovaly do roku 1947.7 Architektonické školení v Paříži, poznání evropské architektury z autopsie, stejně tak i vynikající znalosti z oblasti inženýrských staveb využívajících železobetonových konstrukcí Morganovou předurčovaly jako nejvhodnější osobu, která dokázala zhmotnit Hearstovy představy o podobě jeho snové rezidence. Navrhla většinu objektů rozsáhlého "hradního komplexu“, které s Hearstem podrobně řešila při ústních rozhovorech anebo prostřednictvím písemné korespondence. Rovněž s ním úzce diskutovala integraci jeho rozsáhlé umělecké sbírky do architektonických struktur nebo rozmístění děl na pozemku v okolí hradu ${ }^{8}$ a sama se také podílela na nákupu rozličných uměleckých předmětů potřebných $\mathrm{k}$ dotvoření podoby hradních interiérů. Po dobu osmadvaceti let Morganová dohlížela v podstatě na všechny aspekty spjaté s výstavbou Hearstova hradu.

Panenská př́roda $\mathrm{v}$ blízkosti zátoky San Simeon $v$ poměrně řídce osídleném pobřeží střední Kalifornie, zhruba v pưli cesty mezi San Franciskem a Los Angeles, evokovala pohádkovou krajinu dotvářející ideový rámec hradu tyčícího se na Kouzelném kopci - La Cuesta Encantada, jak byla tato rezidence původně označována. Situování budovy na kopci umožňovalo úžasný výhled na zalesněné pohoří Santa Lucia i na nekonečnou třpytící se hladinu Tichého oceánu. Na druhou stranu tato lokalita přinášela určité obtíže v souvislosti s dovozem stavebního
Hearstův hrad, Casa Grande, západní průčelí, foto Markéta Jarošová

6 Julia Morganová (†1957) vystudovala stavební inženýrství na Kalifornské Univerzitě v Berkeley. Roku 1896 podnikla cestu do Evropy, kde studovala na École des BeauxArts v Paříži. Po ukončeni studií se vrátila zpět do San Francisca, kde si roku 1904 otevřela vlastní architektonickou kancelár. Podílela se na projektech Hearstových nemovitostí, včetně rezidence Wyntoon v severní Kalifornii reflektující architekturu oblasti Bavorského lesa. Blíže k ní: WADSWORTH, Ginger Julia Morgan, Architect of Dreams, Minneapolis: Lerner Publication Company, 1990 nebo WILSON, Mark. Julia Morgan: Architect of Beauty, Layton: Gibbs Smith Publisher, 2007.

7 Hearst svou rezidenci naposledy navštívil roku 1947. Díky zdravotním potižím nadále pobýval už jen ve svém sídle v Beverly Hills. Rokem 1947 se proto datuje ukončení stavební činnosti Julie Morganové, přestože stavba nebyla dokončena $v$ plném rozsahu. 8 Podél Esplanade se nachází mramorové kopie antických soch, mj. Ares Ludovisi, Sedící Merkur, sousoší Zápasníkü, nebo také kopie Canovových Trech Grácií. Ve vrcholu fontány pred Casa del Sol stojí kopie Donatellova bronzového Davida, aj. 


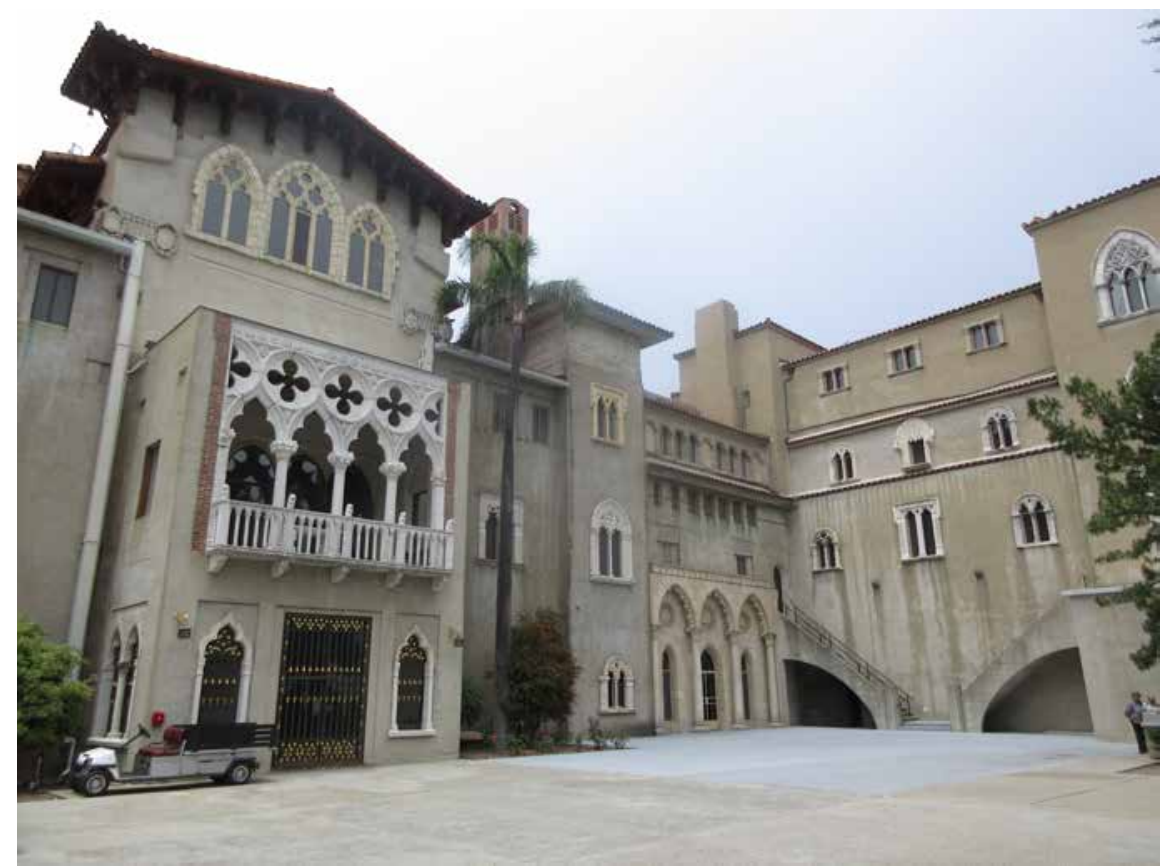

Hearstův hrad, Casa Grande, východní průčelí, foto Markéta Jarošová
9 Odlehlost lokality, obtížnost prepravy stavebního materiálu a zajištění zázemí pro dělníky a řemesIníky výrazně zvyšovalo finanční náklady na cely projekt. $V$ blízkosti San Simeon si Hearst později nechal vybudovat pristávací dráhu pro své osobní letadlo. In: PROCTER, Ben. William Randolph Hearst. Final Edition, 1911-1951.

Oxford: Oxford University Press, 2007, s. 81 a 146. Dnes je prístup $k$ hradu zabezpečen speciální autobusovou dopravou, zahrnující poslechový edukativní výklad při cestě do kopce i zpět k hlavnímu informačnímu centru.
Hearstova hradu. Při výstavbě silnice byla vybudována řada mostů, tvořených železobetonovou konstrukcí, včetně slavného Bixby Creek Bridge. Materiál na výstavbu Hearstova hradu byl v té době proto dopravován především lodní dopravou. Lodě vyplouvaly ze San Francisca a kotvily u mola v zátoce u San Simeon. Z Los Angeles byl materiál dopravován po železnici do San Luis Obispo, odkud byl dále přepravován nákladní automobilovou dopravou. ${ }^{9}$

\section{Architektonická podoba hradu}

Architektonický návrh byl od samého počátku založen na propojení a začlenění objektu do krajiny čili na principu vlastním již antickým, případně renesančním příměstským vilám. Hlavní dominantou unikátního komplexu je reprezentativní sídlo nazývané Casa Grande, charakteristické monumentálním dvouvěžovým průčelím. Obklopovala jej trojice nízkých domů zapuštěných do svahu a pojmenovaných San Simeon byl budován v průběhu let 1919 až 1937, což se prolíná s výstavbou

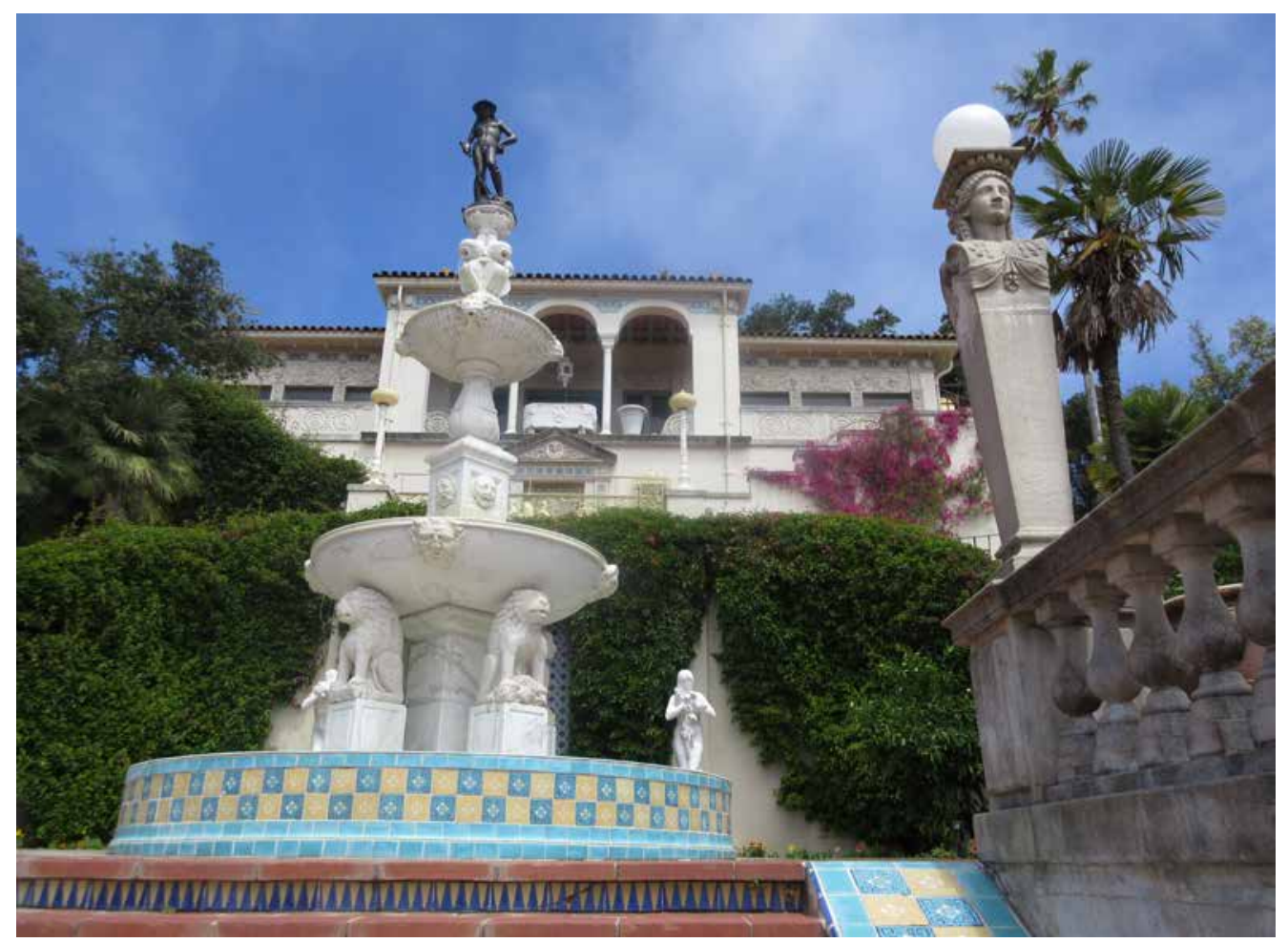

Hearstův hrad, Casa del Sol, foto Markéta Jarošová 
podle orientace průčelí směrem $\mathrm{k}$ pohoří Santa Lucia nebo k Tichému oceánu jako Casa del Monte, Casa del Mar a Casa del Sol, poskytujících ubytování především hostům. Jednotlivé objekty byly propojeny prostřednictvím teras, chodníků a meandrovitě utvářených zahrad nazývaných Esplanade.

$\mathrm{S}$ ideovými návrhy na výstavbu rezidence Hearst seznámil Morganovou v roce 1919 a základní stavební práce započaly roku 1922. Vzhledem k situování stavby na poměrně nedostupném svažitém terénu bylo nejprve zapotřebí zplanýrovat návrší kopce. Jelikož se oblast nachází v seizmickém pásu doprovázeném zemětřesením, s předtuchou možné zkázy projektovala zkušená Julia Morganová tuto stavbu za pomoci využití osvědčené železobetonové konstrukce. $\mathrm{V}$ letech 1923 až 1924 byly položeny základy Casa Grande, na které bylo použito enormního množství betonu, a v letech 1926 až 1928 byla stavba obložena kamennými obklady z bílého vápence, díky čemuž je hlavní

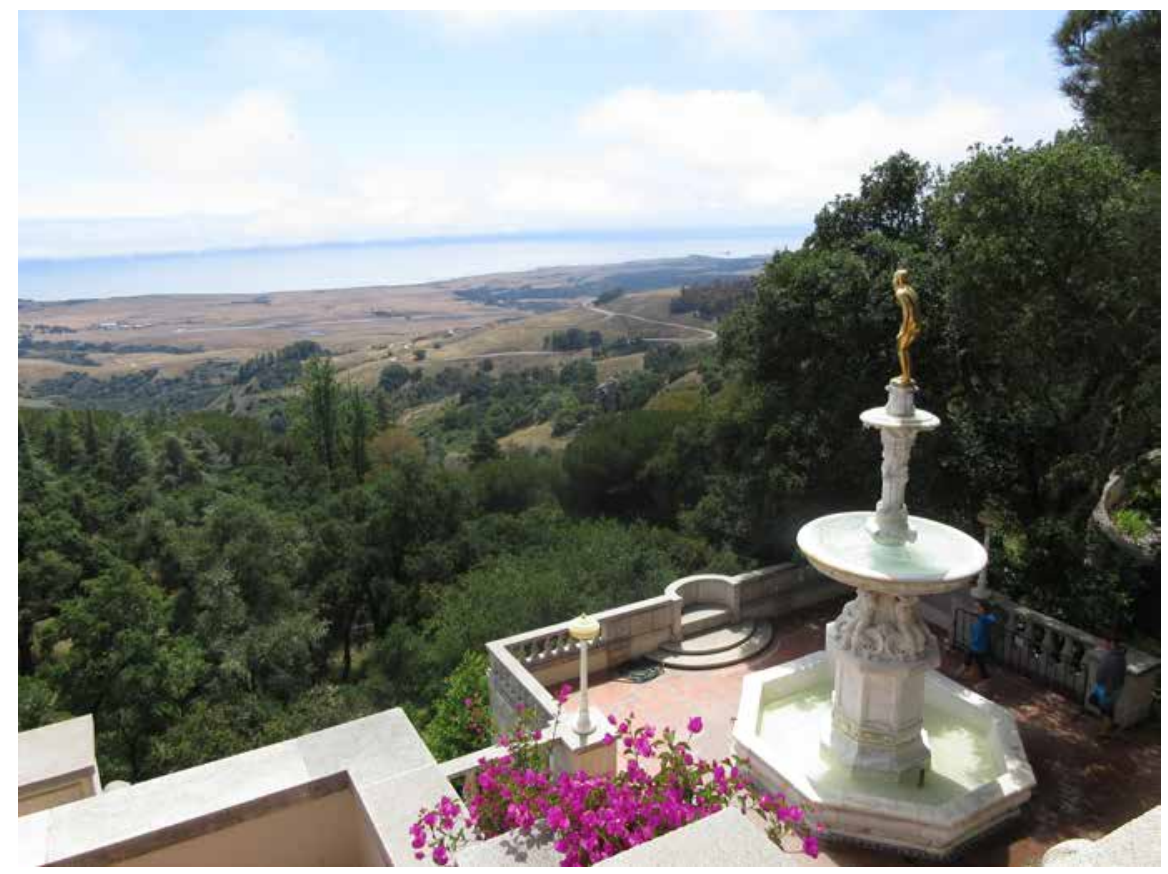

západní průčelí zřetelně viditelné z velké dálky; východní trakt byl v tu dobu ponechán bez obložení a železobetonová konstrukce zůstala na těchto místech exponovaná dodnes. ${ }^{10}$

Julia Morganová se během svých evropských cest seznámila s architektonickými řešeními, které se staly podnětem řady návrhů pro Hearstův hrad. Ovlivněna byla především španělskou a italskou architekturou, jejíž principy jsou charakteristické

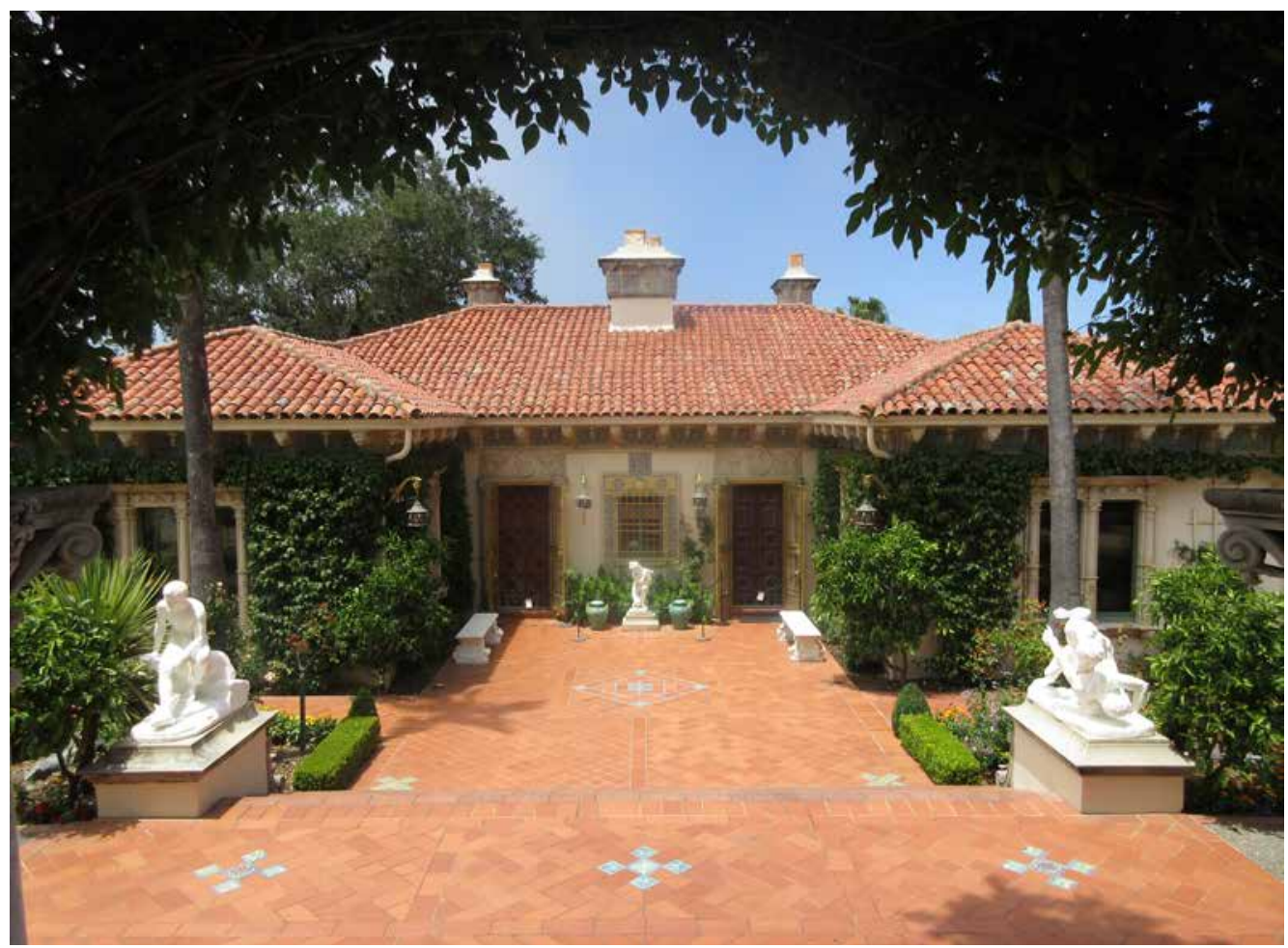

Hearstův hrad, Casa del Monte, foto Markéta Jarošová

10 BROWN, Thomas. The Illustrated History of Hearst Castle. Atascadero: Nouveaux Press, 2016, s. 15-16.

11 Bliže např. NEWCOMB, Rexford. Mediterranean Domestic Architecture for the United States. (Twentieth Century Landmarks in Design, Vol. 9). New York: Acanthus Press, reprint 1999; NEWCOMB, Rexford. Spanish Colonial Architecture in the United States. New York: Augustin Publ., 1937. 12 Centennial Exposition ve Filadelfii v roce 1876 a World's Columbian Exposition, konaná v Chicagu roku 1893. 


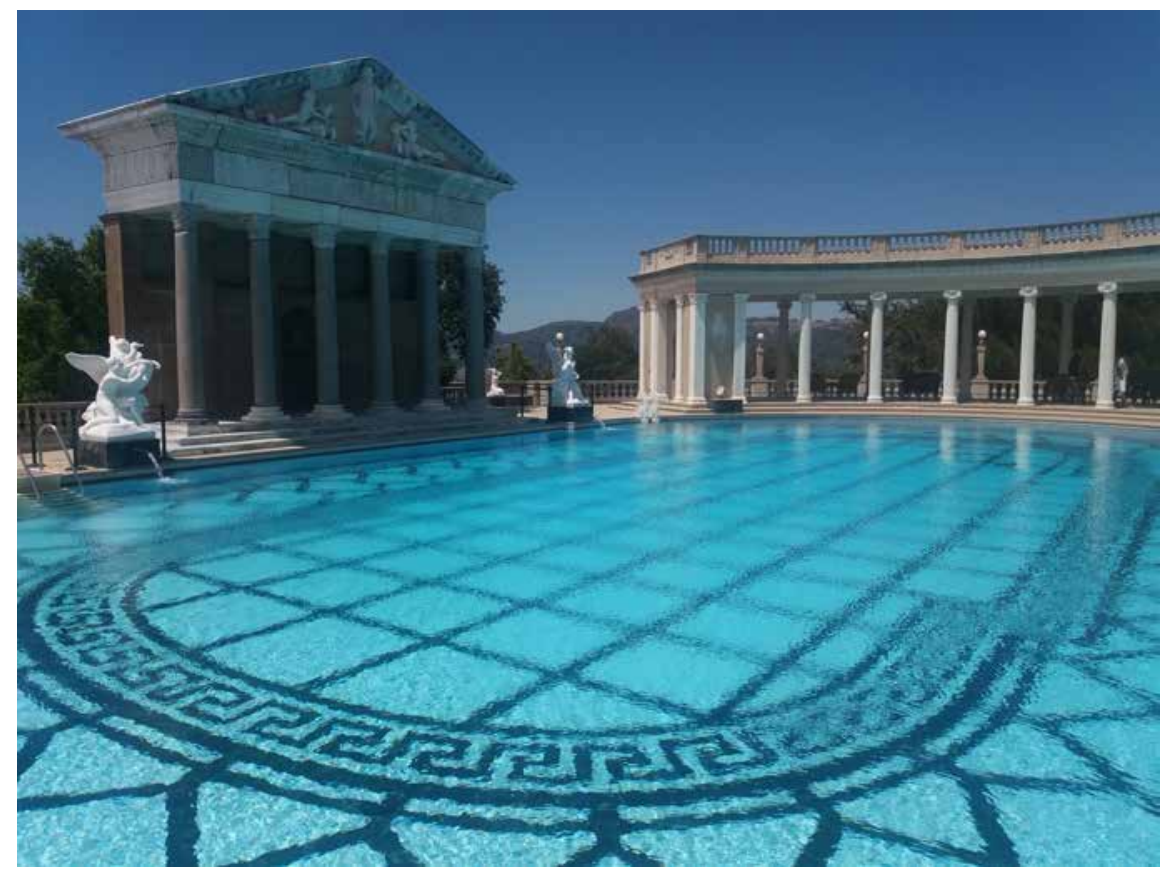

Hearstův hrad, Neptunův bazén, foto Markéta Jarošová pro tzv. Mediterranean Revival Architecture, vrcholící ve Spojených státech ve 20. a 30. letech 20. století. Příznačný středomořský styl paláců a přímořských vil byl uplatněn především v souvislosti s rozvíjející se architekturou $\mathrm{v}$ pobřežních oblastech Kalifornie a na Floridě. ${ }^{11}$

Předpokládaným inspiračním zdrojem pro Hearstův hrad byly rovněž vysoce populární mezinárodní výstavy pořádané ve Spojených státech od konce 19. století, ${ }^{12}$ které podněcovaly zájem Američanů o evropské kulturní dění. William Randolph Hearst se podílel na financování světové výstavy konané v San Franciscu v roce 1915 a předpokládá se, že právě tato výstava mohla zčásti ovlivnit návrhy pro hradní komplex u San Simeonu. V souvislosti s výstavou oslavující otevření Panamského průplavu byla realizována řada staveb ve španělsko-maurském stylu, ${ }^{13}$ který Hearst upřednostňoval v rámci architektonického ztvárnění své rezidence. Dvouvěžová hlavní fasáda Casa Grande s bohatě řešeným vstupním portálem opatřeným sochařskou výzdobou doslova evokuje katedrální průčelí španělské Mediteriánské oblasti a je tak v kontrastu s trojicí nízkých apartmánů, připomínajících spíše příměstské vily na italském pobřeží. Středomořskou atmosféru završuje přírodní prostředí, které dotváří jedinečnost celého tohoto komplexu. Velká pozornost byla věnována osazení řady exotických stromů, keřů a výsadbě rostlin v zahradách. ${ }^{14}$
13 Panama-Pacific International Exposition byla pořádaná v San Franciscu roku 1915 a v letech 1915-1916 proběhla výstava PanamaCalifornia Exposition v Balboa Parku v San Diegu. Bliže např: GANZ, James A. ed. Jewel City. Art from San Francisco's Panama-Pacific International Exposition. San Francisco: Fine Arts Museum, 2015.

14 Hearst vynaložil mnoho finančních prostředků na přepravu již vzrostlých stromů a zrídil zde také zoologickou zahradu. Vedle stád buvolů, losů a jelenů se $v$ zahradách procházeli lvi, žirafy, zebry, pakoně nebo treba klokani. In: PROCTER, Ben. William Randolph Hearst. Final Edition, 1911-1951. Oxford: Oxford University Press, 2007, s. 123.

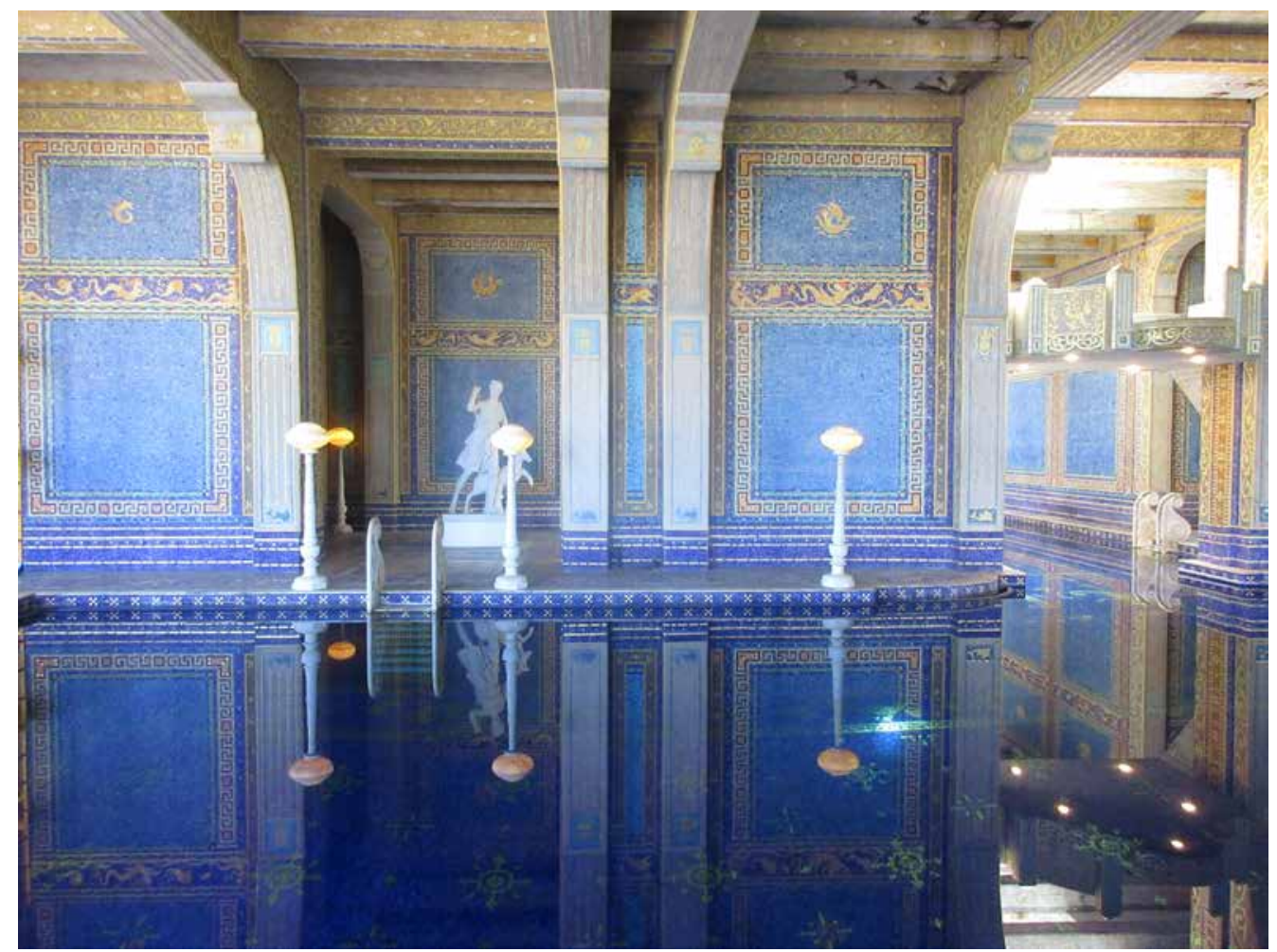

Hearstův hrad, Římský bazén, foto Markéta Jarošová 
Architektonickou podobu rezidence dotvářely originální umělecké prvky evropského původu z různých časových období, které byly průběžně vkomponovávány do exteriéru i interiéru stavby. $\mathrm{K}$ nejvýraznějším prvkům patři vedle vstupních portálů, ostění, okenních rámů a krbů především dřevěné stropy italské a španělské provenience datované od pozdního 14. do 18. století. Některé novodobé dřevěné stropy byly při instalaci záměrně poškozeny, aby bylo dosaženo efektu starobylého vzhledu. Při budování stavby neustále docházelo $\mathrm{k}$ revizi původních plánů a znovu a znovu se přemýšlelo o jednotlivých detailech.

Vše bylo podřízeno výlučně Hearstově vizuální estetice. Snil o idylické rezidenci, která by zároveň sloužila jako schrána pro umělecké poklady, které systematicky shromaždoval po celý svůj život. Ovšem pouze část z Hearstovy legendární sbírky zde byla prezentována. ${ }^{15}$ Při svých akvizicích věnoval pozornost nejen obrazům a sochám, ale také předmětům užitého umění, zejména nábytku. Casa Grande s reminiscencemi středověké a renesanční architektury, vybavená početnou kolekcí uměleckých děl evropské provenience, tvoří vskutku výjimečný celek. Unikátní architektonické prostředí, v němž prezentované stř̌edověké a novověké umělecké předměty nejenže demonstrují majitelovo bohatství, ale především navozují dojem autentické starobylosti, je díky zvolenému muzeologickému prístupu dochováno dodnes.

\section{Bazény}

Ke skvostům okázalého hradního komplexu náleží dvojice bazénů. Výstavba venkovního bazénu probíhala $\mathrm{v}$ letech 1924-1936, přičemž i v tomto př́ipadě došlo k proměnám původních plánů, jejichž výsledkem bylo výrazné rozšíření a nápaditější architektonická podoba. Dominantu tvoří průčelí evokující rímský chrámový portikus, situovaný na střední ose bazénu, k němuž se obrací dvojice konkávně linoucích se kolonád, poskytujících koupajícím

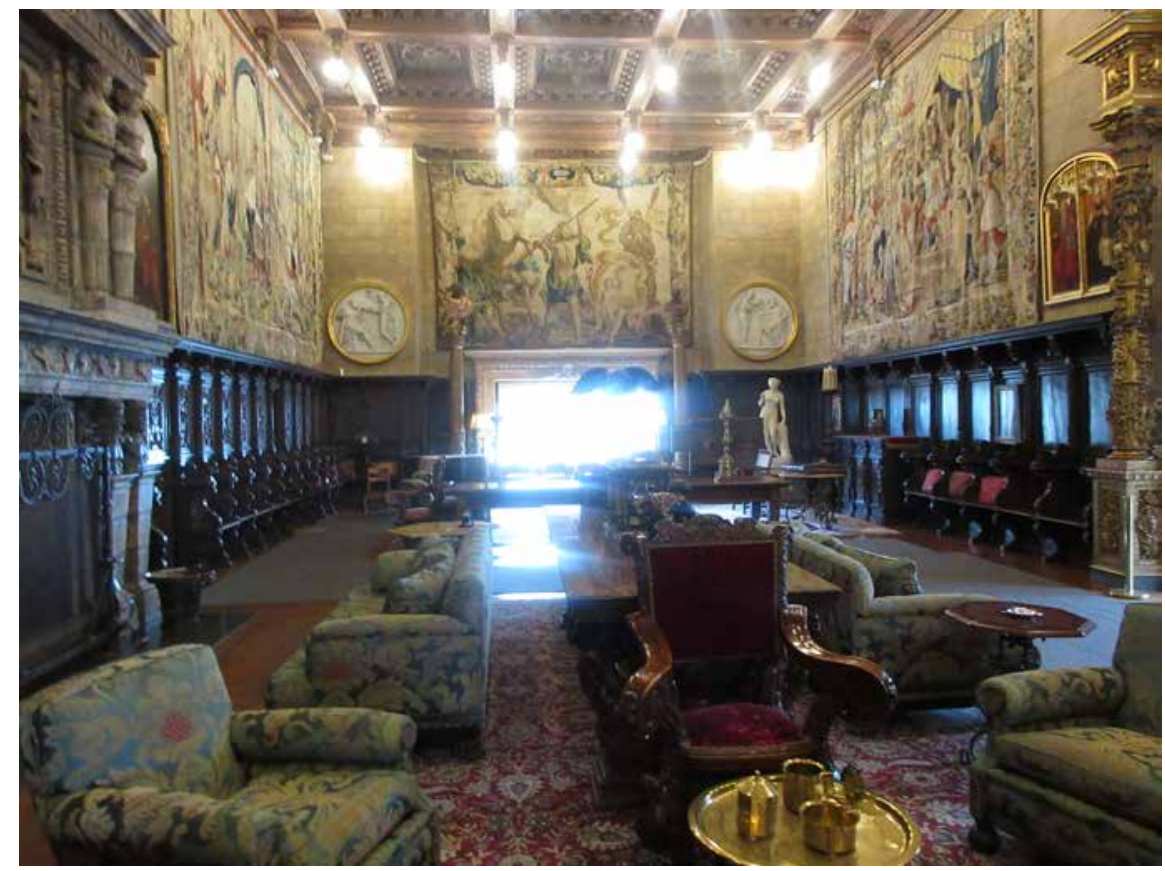

se úkryt před žhavým sluncem. Na obložení bazénu a dekorativní prvky, imitující římský architektonický výzdobný aparát, včetně ozdobných mramorových zábradlí, bylo použito vermontského mramoru. Venkovní bazén je nazýván Neptunův, a to na základě zamýšleného sousoší zobrazujícího božstvo jedoucí na koňském čtyřspřeží, které mělo kontrastovat s chrámovým portikem. ${ }^{16}$ Sochařskou výzdobu v prostoru plytké bazénové niky dnes představuje pouze Zrození Venuše

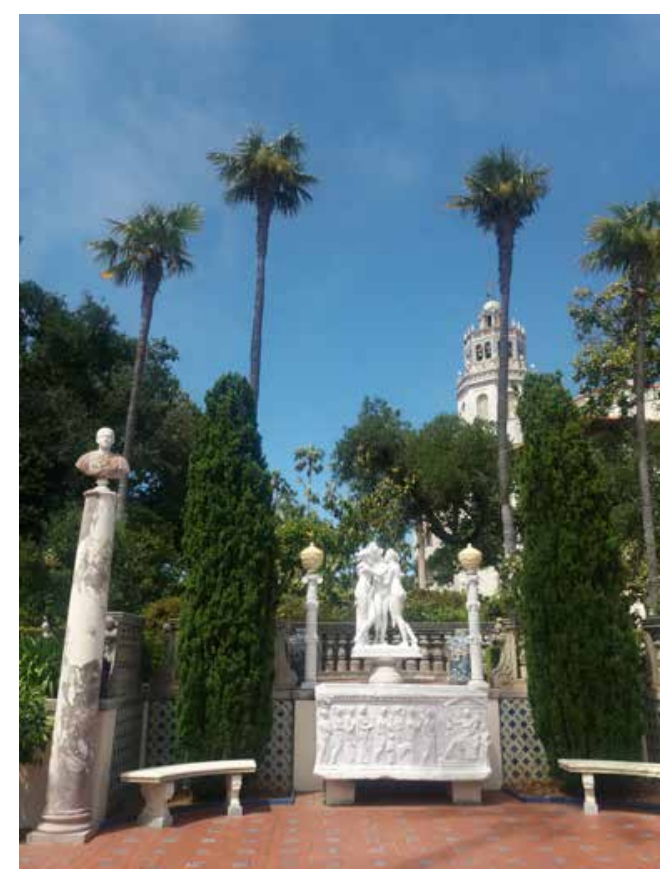

Hearstův hrad, Esplanade, rímský sarkofág a kopie Canovova sousoši Třech grácií, foto Markéta Jarošová
Hearstův hrad, Casa Grande, interiér sněmovní síně, foto Markéta Jarošová

15 Jistým předobrazem rezidence $v$ San Simeon byl tzv. Claredonův düm na Manhattanu, který Hearst vybavil pozoruhodnou sbírkou středověkého brnění a dalšími gotickými a renesančními dily, včetně tapisérií. I když Hearst vlastnil mnoho skvostných nemovitostí v New Yorku, Manhattan mu pripadal "jako jedna velká kancelářská budova", a zvláště v závěru svého života upřednostňoval slunné kalifornské prostředí.

16 Vzhledem $k$ vypuknutí 2. sv. v. se sousoší do USA dostalo až po jejím skončení, avšak při požáru skladiště v New Yorku roku 1956, v němž bylo uskladněno, bylo zničeno a jeho podobu dnes dokládaji pouze nákresy a dobové fotografie. BROWN, Thomas. The Illustrated History of Hearst Castle. Atascadero: Nouveaux Press, 2016, s. 82. 


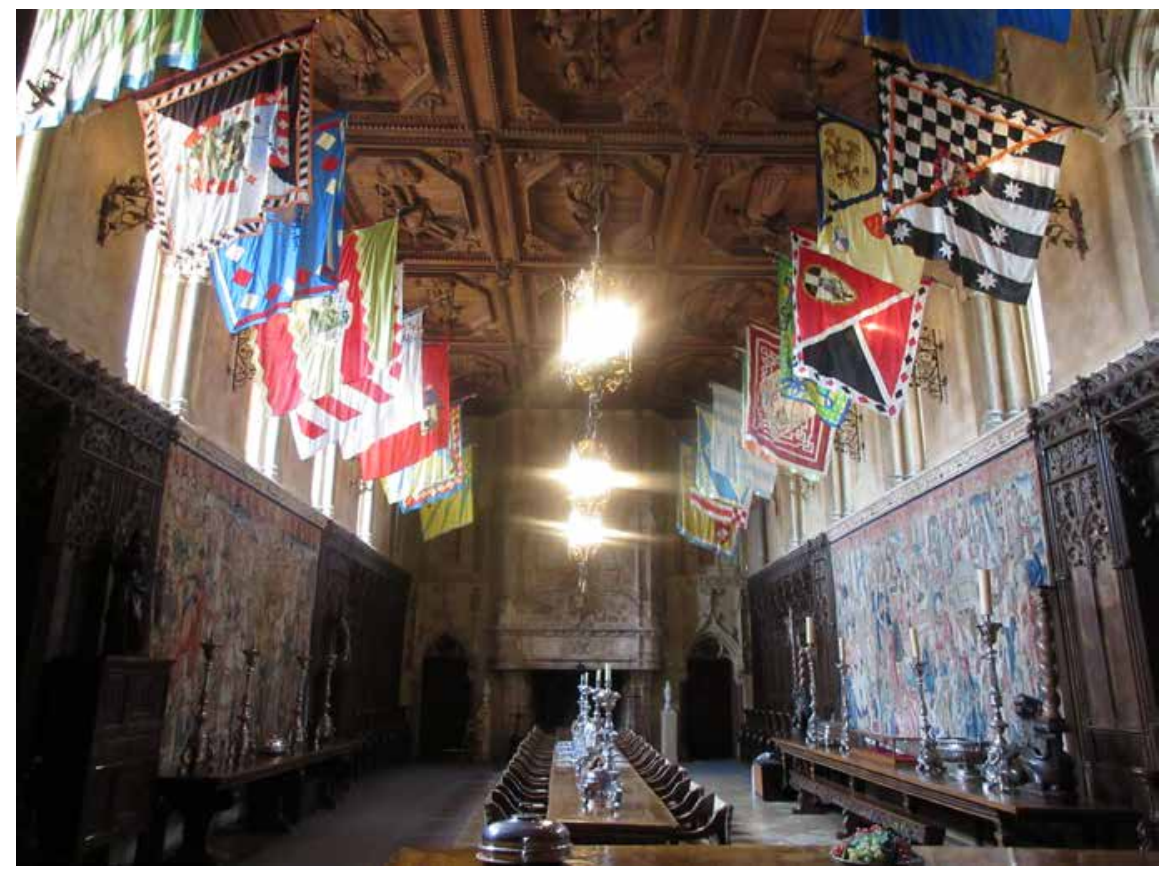

Hearstův hrad, Casa Grande, interiér tzv. refektáře, foto Markéta Jarošová

17 Za inspirační zdroj bazénu jsou pokládány Caracallovy lázně v Rímě, budované na počátku 3. století. Poukazováno je ovšem i na mozaikovou výzdobu mauzolea Gally Placidie $v$ Ravenně z 5. století. Afinita je spatřována $v$ uplatnění modré a zlaté barvy a ve stylizovaných vzorech hvězd. In: http://hearstcastle.org/ history-behind-hearst-castle/ 18 Nachází se zde mj. kopie Polykleitova Doryfora, Feidiovy Raněné Amazonky či Leocharovy Diany z Versailles, tzn. príklady, které souvisí s evropskými veřejnými muzei (Kapitolská muzea, Vatikánské sbírky, Archeologické muzeum v Neapoli nebo Louvre), a $v$ řadě dalších muzejních expozicích byla tato slavná antická sochařská díla prezentována nejčastěji formou sádrových odlitků.

19 Jde o jednu ze trí verzí, kterou Canova vytvoril z pověření Napoleona podle vzoru Venuše Medicejské chované ve sbirkách Uffizi. Tuto sochu společně s dalšími slavnými dily nechal Napoleon roku 1802 převést do Louvru. Jednu z Canovových soch zakoupil Napoleonův bratr Josef, který ji prodal markýzi Lansdownovi. 20 Z Evropy byla umělecká díla transportována lodní dopravou. Prepravní bedny byly vyloděny v New Yorku a odtud dopraveny železnicí my. Bazén je od podlahy ke stropu po smalti - drobnými skleněnými dlaždicemi

s nymfami - zlomek z původního velkolepého konceptu. Sousoší z carrarskéh v letech 1924 až 1936.

Zcela unikátní je rovněž krytý bazén, budovaný v letech 1927 až 1934, který svým charakterem evokuje starověké ŕímské tersmati-drobnými skleněnými dlaždicemi čtvercového formátu. Intenzivní modrá a třpytivá zlatá barva dlaždic, odrážejících se ve vodní hladině, vytvárí vskutku dechberoucí efekt. Návrhem mozaikové výzdoby byla pověřena Camille Solon, freskařka francouzského původu, která pojala strop bazénu jako nebeskou oblohu posetou zlatými hvězdami. $\mathrm{V}$ rámci výzdobného repertoáru se zde objevují tradiční mořská monstra, př́íznačná pro ikonografickou výzdobu starověkých rímských lázní a znamení zvěrokruhu. ${ }^{17}$

Navození atmosféry římských lázní umocňuje rozmístění osmi mramorových soch. Těmito kopiemi slavných antických děl ${ }^{18}$ podle originálů byl pověřen Carl Freter, který na jejich zhotovení pracoval od roku 1930 v italské Pietrasantě. Součástí skupiny je socha Apoxyoména, kterou Freter vyhotovil na základě věrné kopie Lysippovy antické sochy, chované ve vatikánských sbírkách. Avšak nejen v př́ípadě výzdoby bazénů můžeme pozorovat úzkou vazbu ke kontextům umění římského impéria.

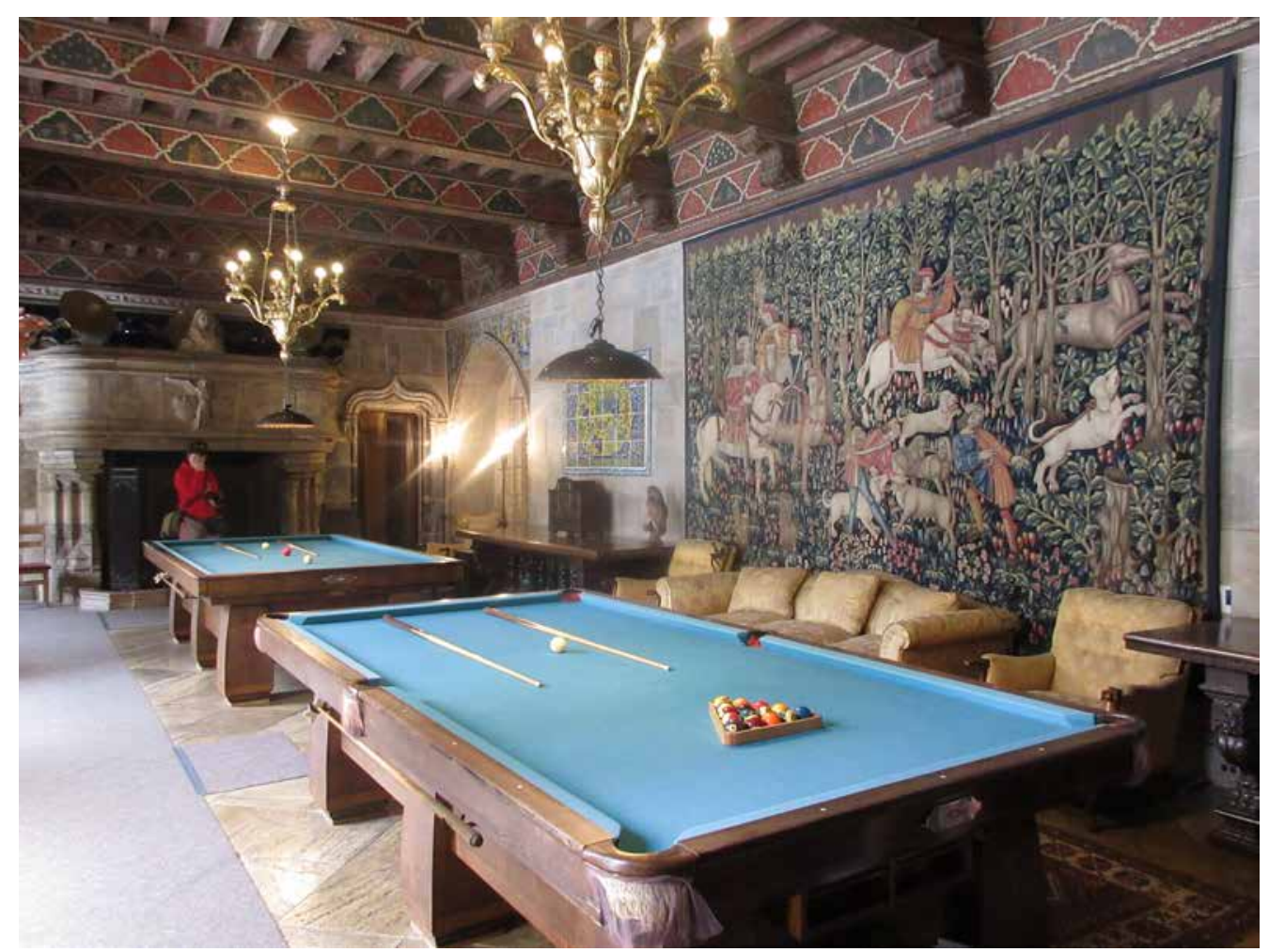

Hearstův hrad, Casa Grande, interiér tzv. kulečníkové místnosti, foto Markéta Jarošová 


\section{Hearstova umělecká sbírka}

Za jedno z mistrovských děl Hearstovy umělecké kolekce je pokládána Canovova Venuše Italica, kterou získal společně s několika antickými římskými sochami ze sbírky věhlasného anglického sběratele, markýze Lansdowna v roce $1930 .^{19}$ Hearst, stejně jako ostatní velcí sběratelé té doby, získával umělecká díla prostřednictvím obchodníků s uměním a aukčních domů, kterými byli mj. Georges Wildenstein, Joseph Duveen, M. Knoedler \& Co., Gimbel Brothers, aj. Bylo využito rozličných cest a dopravních prostředků v závislosti na zdroji nebo místě, odkud byla zásilka pro Hearstův hrad odeslána. ${ }^{20}$ Hearst se při svých nákupech spoléhal na analýzy a názory prodejců, i když i oni se $\mathrm{v}$ mnoha případech mýlili, jak ostatně prokázaly pozdější výzkumy.

Horečný nákup uměleckých děl a jejich následná prezentace $\mathrm{v}$ soukromých sídlech byly pro Hearsta vysoce prestižní záležitostí. Zatímco pro sídlo Wyntoon v severní Kalifornii byla určena velká část sbírky uměleckých děl německé provenience, v rezidenci v San Simeon byla koncentrována především díla španělského a italského původu. ${ }^{21}$ Svou uměleckou sbírku Hearst výrazně obohatil nákupy po první světové válce a zejména v důsledku Velké hospodářské krize, kdy došlo k rozprodeji řady evropských uměleckých sbírek ze šlechtických i církevních kruhů, které se dostaly v mnoha případech do rukou zámožných Američanů. Americký trh byl zaplaven evropskými uměleckými díly, které bylo možné získat za výhodnou cenu. Na pozadí celosvětové hospodářské krize třicátých let si tak Hearst, soupeřící s majestátností evropské aristokracie, budoval své umělecké kolekce. Sbírka v San Simeon vkomponovaná do architektonického rámce zřetelně vypovídá o snaze napodobit evropská aristokratická sídla s dlouholetou tradicí, kde byly rodinné sbírky budovány mnoha generacemi. Na stěnách Hearstova hradu visí portréty, zřetelně odkazující na slavné evropské rodové galerie. K symbolickému

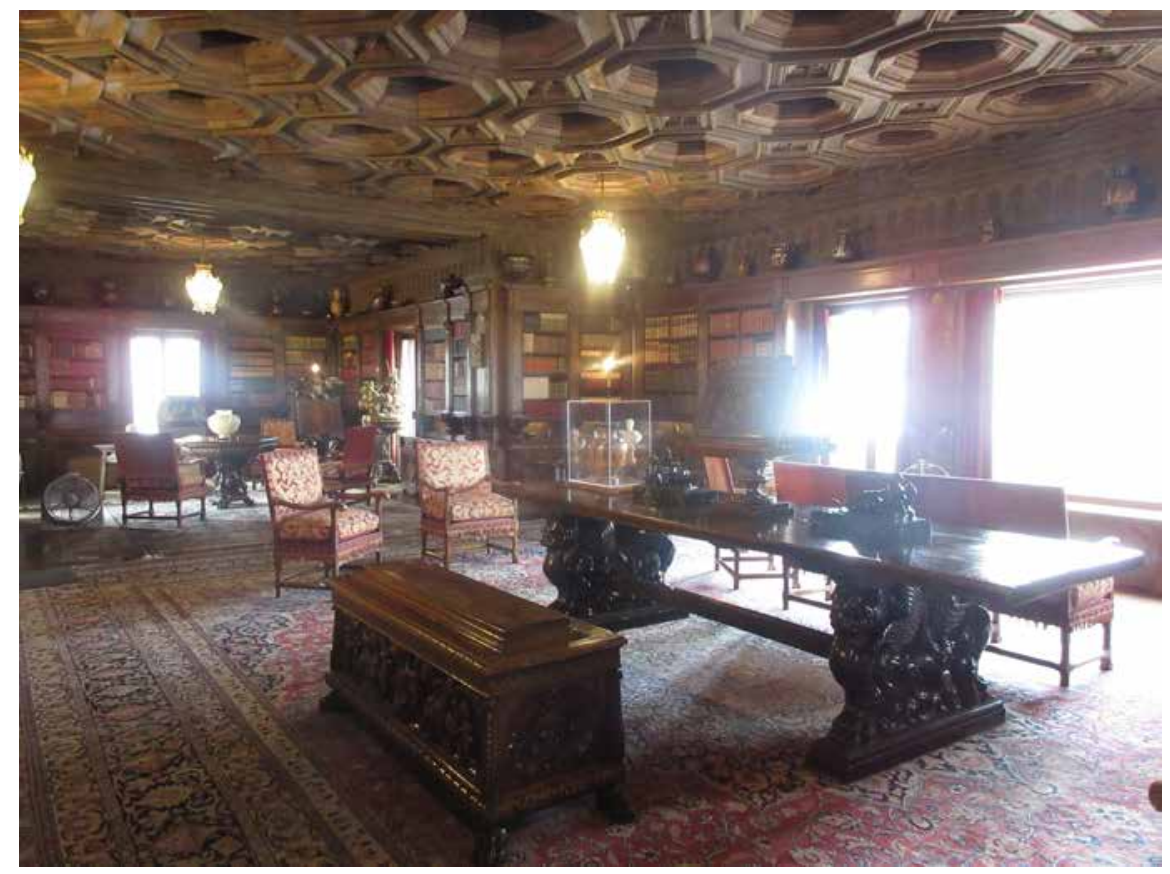

„Ztotožnění se" se svými vzory přispělo promísení zakoupených uměleckých děl s osobními předměty z majetku Hearstovy rodiny.

Hearstova sběratelská povaha se vyznačovala obrovskou rozmanitostí. Skupoval starověké egyptské a antické starožitnosti včetně bohaté kolekce řeckého vázového malířství, díla středověkého a novověkého umění i módního art deca. Sloučení starožitností a moderních uměleckých děl přineslo jedinečný výsledek. Kromě evropského umění směřoval pozornost také k asijskému umění a stejně tak inklinoval $\mathrm{k}$ artefaktům původních amerických kultur, v čemž byl nepochybně ovlivněn svou matkou. ${ }^{22}$ Nepřeberné množství uměleckých předmětů v Hearstově sbírce prezentuje četné kultury napříč staletími i kontinenty. Tato snaha zahrnout do sbírky artefakty ze všech koutů světa poukazuje na Hearstovo evropské poučení a znalost zdejších muzejních institucí soustředěných na integraci "světového umění", jakým bylo Britské muzeum nebo Louvre. Shromážděné artefakty, zasazené do architektonického řešení, instalačně nejvíce podtrhly hmatatelné spojení s dávnou evropskou kulturní tradicí.

Po své matce získal Hearst početnou sérii barokních tapisérií a orientálních koberců vysoké umělecké kvality, které dodnes pokrývají podlahy nebo slouží jako ozdobné závěsy $\mathrm{v}$ místnostech, a sám s velkou vášní nakupoval širokou škálu předmětů užitého umění. Koncentrace na historický
Hearstův hrad, Casa Grande, interiér knihovny, foto Markéta Jarošová

do San Francisca a poté lodí do San Simeonu. Z Los Angeles byly posilány vlakem do San Luis Obispo a poté nákladním automobilem do San Simeonu. Pro lodní dopravu byl využíván rovněž Panamský průplav, zprovozněný v roce 1914. 21 Kolekce stříbra byla určena zejména pro středověký hrad St. Donat ze 14. století ve Walesu, který Hearst zakoupil roku 1925. PROCTER, Ben. William Randolph Hearst. Final Edition, 1911-1951. Oxford: Oxford University Press, 2007, s. 124.

22 Phoebe Hearstová (+1919) významně podporovala Kalifornskou univerzitu v Berkeley, kde bylo roku 1901 založeno Antropologické muzeum, na jehož zrodu se podílela. Uvědomovala si význam kultury domorodých obyvatel, a proto podporovala antropology zabývající se mj. výzkumem kalifornské historie a kultury. Muzejní sbírka je dodnes součástí Kalifornské univerzity v Berkeley a od roku 1991 nese název Phoebe $A$. Hearst Museum of Anthropology. $23 \mathrm{~V}$ souvislosti s akvizicemi nábytku španělské provenience jej Morganová varovala před padělky, které mnozí obchodníci s uměním prezentovali za dila autentická. Hearst, přestože o pochybné pravosti nabízeného dobového nábytku věděl, prohlašoval, že jde 


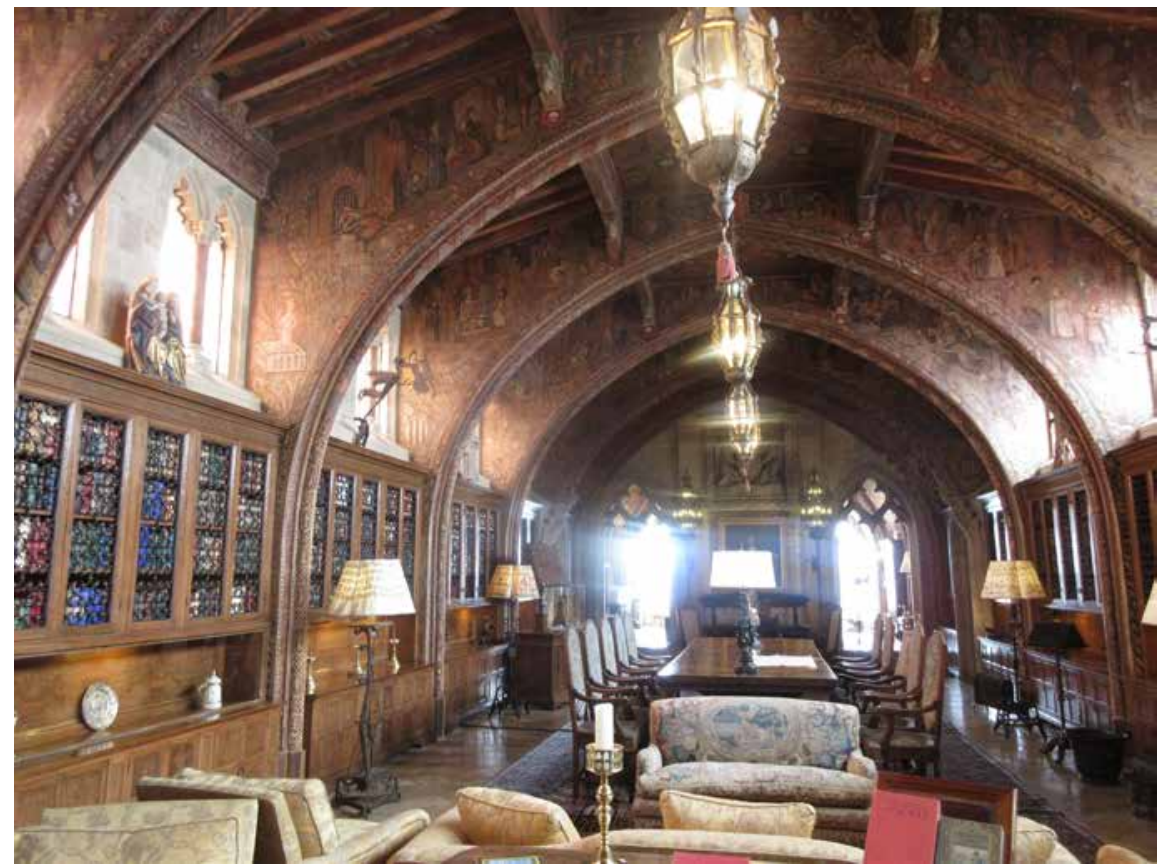

Hearstův hrad, Casa Grande, interiér tzv. gotického apartmá, foto Markéta Jarošová

o materiál nesmírně důležitý pro vybavení hradu, a v nákupech proto pokračoval.

24 Pravidelně se zde scházela rada prominentních hollywoodských herců, spisovatelé, sportovci, ale také rada predstavitelů politického života, jako byli Charlie Chaplin, Greta Garbo, G. B. Shaw, Albert Einstein, Charles Lindbergh, Andrew Mellon i Winston Churchill. In: PROCTER, Ben. William Randolph Hearst. Final Edition, 1911-1951. Oxford: Oxford University Press, 2007, s. 131 a 139.

25 Úzkou paralelu s prezentací uměleckých děl v soukromých apartmá Ize spatřit napríklad $v$ newyorských rezidencích Morgana a Fricka, bostonském Fenway Court Isabelly Stewart Gardnerové anebo v prezentaci sbírky Roberta Lehmana $v$ Metropolitan Museum of Art $\checkmark$ New Yorku.

26 Hearstovy mecenášské aktivity pripomněla roku 2008 výstava konaná v LACMA, která představila přibližně sto sedmdesát děl z jeho majetku. Jejím cílem bylo opětovně sestavit a kontextualizovat, co Hearst shromáždil. Při té príležitosti byla publikovaná kniha: LEVKOFF, Mary L. Hearst the Collector. Los Angeles: Los Angeles County Museum of Art, 2008. nábytek bezesporu souvisela s potřebou vybavit interiéry svých početných rezidencí židlemi, stoly, postelemi, truhlami, komodami a skříněmi - v případě sledované Hearstovy hradní rezidence nejčastěji španělské nebo italské provenience. ${ }^{23}$ Tato pestrost a množství nábytku jsou dnes vysoce ceněny $\mathrm{v}$ souvislosti s výzkumem nábytkářských výrobních technik a designu.

\section{Casa Grande}

Rozmístění uměleckých děl z různých epoch, provenience nebo výtvarné kvality určuje charakter jednotlivých místností a podtrhuje jejich symbolický význam. K nejvelkolepějším prostorám Casa Grande čený k setkání Hearsta se svými hosty. Spodní části stěn místnosti jsou pokryty ořechovým obložením, horní zdobí renesanční a barokní tapiserie a závěsné obrazy. Na reprezentativní význam tohoto sálu poukazuje situování zmíněné Canovovy Venuše Italicy. Další ikonickou prostorou je jídelna, nazývaná refektár̆. Ačkoli terminologií prostor symbolicky odkazuje na středověký klášter, svým charakterem a výzdobou spíše imituje světskou hodovní síň. Sluneční paprsky procházející vitrážemi vysoko posazených sdružených oken umocňují „mystickou“ atmosféru tohoto prostoru. Právě zde se odehrávaly proslulé Hearstovy honosné večeře. „Být na seznamu hostů a sedět u stolu“ bylo pro Hearstovo společenství náleží rozlehlý sněmovní sál v přizemí ur- hollywoodských hvězd vysoce prestižní záležitostí. ${ }^{24} \mathrm{Na}$ evropskou tradici poukazují mj. pestré barevné hedvábné závěsy ukotvené v podokenní zóně - palio delle contrade, odkazující na koňské dostihy pořádané na náměstí Piazza del Campo v italské Sieně již od středověku. Stěny refektáře pokrývají vlámské tapiserie a $\mathrm{v}$ nízkých vitrínách je prezentováno drobné užité umění. Dalším specifickým prostorem je kulečníková místnost se španělským stropem z 15. století dekorovaným scénami z dvorského života a i v tomto př́ípadě plochu stěny pokrývá rozměrná vlámská tapiserie z doby okolo roku 1500. K reprezentativním místnostem patří ještě knihovna situovaná $\mathrm{v}$ patře budovy. Na dřevěných knihovnách naplněných svazky knih, linoucích se podél obvodových stěn místnosti, je prezentována kolekce řeckého vázového malírství. Hearst trávil většinu času ve své pracovně - gotickém apartmá, odkud v závěru svého života $\mathrm{v}$ podstatě řídil své novinové impérium. Patro budovy bylo dále vyhrazeno soukromé Hearstově ložnici se stropem ze 14. století pocházejícím

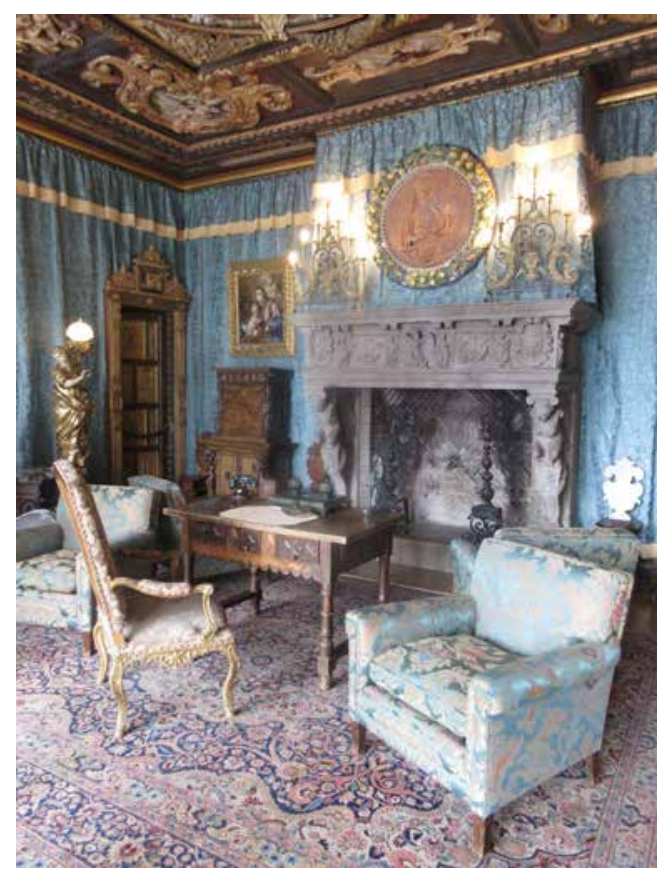

Hearstův hrad, Casa Grande, interiér apartmá pro hosty, foto Markéta Jarošová 
$\mathrm{z}$ aragonského Teruelu, avšak vybavené pohodlným soudobým nábytkem zakoupeným v obchodních domech v Los Angeles. Nebeské a dóžecí apartmá a další pokoje, včetně koupelen, využívali hosté.

$\mathrm{V}$ podstatě všechny místnosti $\mathrm{v}$ přízemí i patrech jsou vybaveny kvalitními i provinčními př́klady deskové malby, sochařskými díly nebo drobným dekorativním uměním. Hearst byl přesvědčen, že jedinečné výstavní prostory, v nichž se mísila stará i soudobá umělecká díla, měly nejenže prakticky sloužit, ale vzbuzovat rovněž potěšení a koneckonců hosty vzdělávat. ${ }^{25}$ Kromě osobní potěchy z uměleckých děl prezentovaných ve vlastních sídlech, bylo pro zámožné sběratele příznačné, že řadu uměleckých předmětů věnovali muzejním institucím. Tímto aktem $\mathrm{v}$ podstatě utvořili jádra sbírek nejvýznamnějších veřejných muzeí ve Spojených státech a ani Hearst nebyl výjimkou. Z Hearstovy sbírky nejvíce uměleckých předmětů získalo Los Angeles County Museum of Art. ${ }^{26}$

Novinový magnát William Randolph Hearst proslul rovněž jako filmový producent, a tak $\mathrm{v}$ jeho rezidenci nesmělo chybět divadlo-kino, kde svým hostům promítal zpravodajství a filmy, v nichž zářila hollywoodská filmová hvězda Marion Davies, Hearstova milenka, ${ }^{27}$ jejíž osobu společně s Hearstem karikoval Orson Welles ve slavném filmu Občan Kane z roku 1941.28

\section{Občan Kane}

Architektonická podoba i interiérové vybavení Hearstova hradu tvoří významovou paralelu bájného Xanadu "největšího soukromého zábavního centra na světě, kde v poušti na pobřeži Golfského zálivu byla objednána a úspěšně vystavěna soukromá hora, na jejizz výstavbu bylo zapotřebí tisíc tun mramoru a sto tisíc stromü, které bylo na ní zasazeno. Až od dob pyramid je Xanadu nejnákladnější monument, který si člověk nechal sám sobě vystavět." Wellesovo filmové zpracování psychologicky rozpracovává řadu významových rovin sbírky a jejího sběratele. Ačkoli se Hearst vưči uvedení filmu na plátna kin ostře ohradil a všem

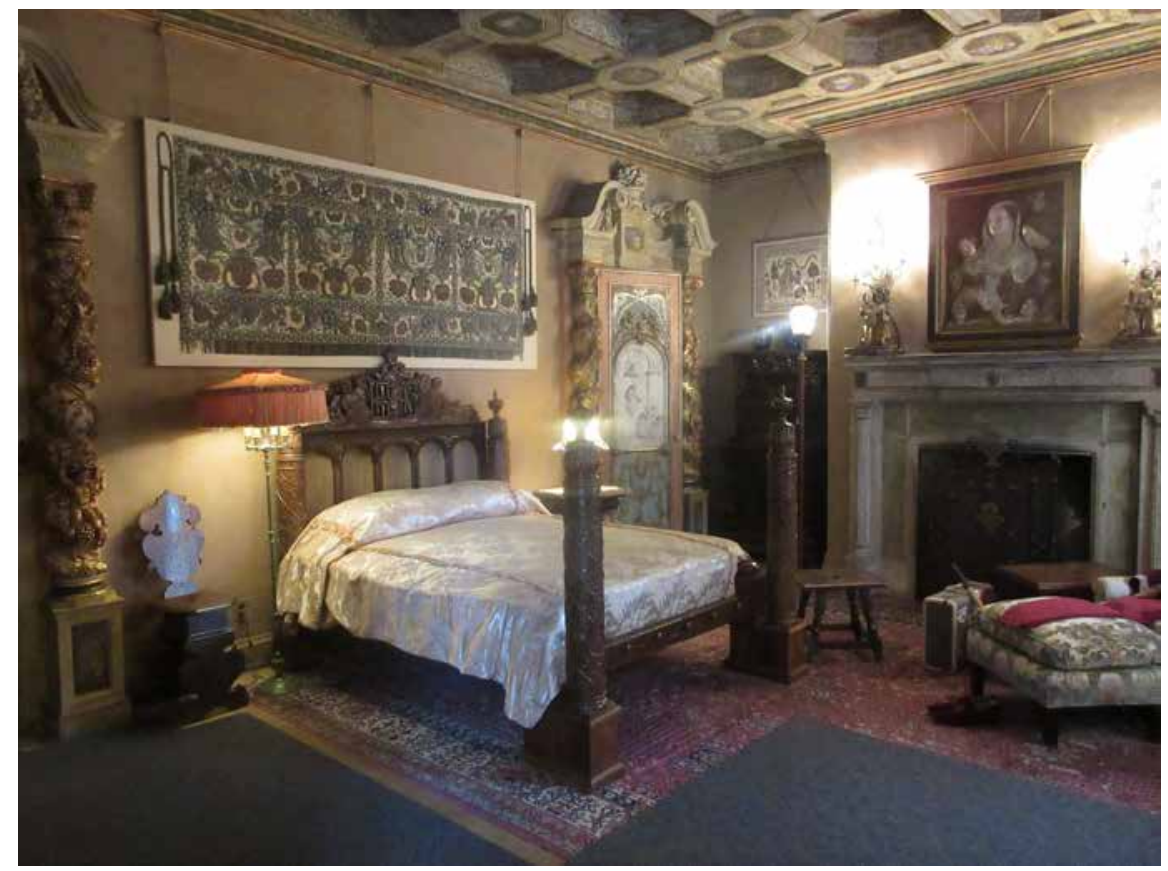

svým nakladatelstvím zakázal jakoukoliv propagaci tohoto filmu, stalo se $z$ něj nakonec jedno z nejslavnějších děl světové kinematografie. Orson Welles na otázku, zda se film zakládá na skutečných životních osudech Williama Randolpha Hearsta vysvětlil: "Bylo nezbytné, aby můj hrdina byl sběratelem - člověkem, který nikdy nic nevyhodí. Chtěl jsem na konci filmu použít symbol, rozsáhlou sbírku předmětů, tisíce a tisíce nejrozličnějších věcí, mezi nimiž se nachází i Poupě. ${ }^{29}$ Tato hromada nehybných divadelních rekvizit je doslova smetištěm jednoho lidského života. Chtěl jsem, aby se $v$ záběru kamery objevily věci nádherné, věci ošklivé $i$ věci úplně zbytečné - jinými slovy všechno, co mohlo zastupovat veřejný $i$ soukromý život. Chtěl jsem, aby se tam nacházely předměty umělecké, předměty upomínkové $i$ docela obyčejné. Neexistuje jiný způsob, jak toho dosáhnout, než udělat ze svého hrdiny sběratele a vybavit jej velkým domem, v němž mohl své sbírky přechovávat. Dưm samotný měl být doslova dramatickým zhmotněním obrazu "slonovinové věže". ${ }^{0}$

Roku 1942 byl film oceněn Oscarem za nejlepší původní scénář ${ }^{31}$ a několik jeho dialogů může reflektovat Hearstovy nákupy evropského umění, například v rozhovoru Kanea s Bernsteinem: ${ }^{32}$ Kane: „,... Př́śtí týden jedu do zahraničí na dovolenou. Už nějakou dobu slibuji svému doktorovi, že si dám volno..." Bernstein: „...slibte, že je v Evropě ještě spousta obrazů a soch, které jste zatím nekoupil." Kane: "Nemůžete mi to mít za zlé..., tvořili tam sochy více než dva

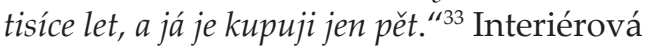

Hearstův hrad, Casa Grande, interiér ložnice pro hosty, foto Markéta Jarošová

27 DAVIES Marion: The Times We Had: Life with William Randolph Hearst. PFAU Pamela, MARX Kenneth S., eds. New York: Ballantine Books, 1987. 28 MULVEYOVÁ, Laura. Občan Kane. Citizen Kane. Praha: Casablanca 2009.

$29 V$ celém příběhu jde o rozluštění významu „poupěte", posledniho slova, které Kane vyslovil na smrtelné posteli. "Poupě" souvisí s nápisem na sáňkách symbolizujících Kaneovo dètství. Podle Mulveyové „poupě" ve filmu propojuje všechna komplikovaná témata týkající se shromažd'ování "věci". In: MULVEYOVÁ, Laura. Občan Kane. Citizen Kane. Praha: Casablanca 2009, 84.

30 Ibidem, 84.

31 Současně byl nominován za nejlepši film, režii, nejlepší herecký výkon $v$ hlavní roli, kameru, hudbu, zvuk, střih a dekorace.

32 Uvedené citace jsou z filmu Občan Kane [Citizen Kane] [film]. Režie Orson WELLES. USA, RKO Pictures, 1941.

$33 V$ technickém scénári se nachází ještě Bernsteinưv dovětek, cit: „Máme už devět Venuší, šestadvacet Panen Marií - dvě skladiště zaplněná po střechu. Slibte mi, pane Kane, že je neskoupíte všechny!". In: MULVEYOVÁ, Laura. 
Občan Kane. Citizen Kane. Praha: Casablanca 2009, 66. $34 \mathrm{~K}$ problematice Wellesova filmu a Williama Randolpha Hearsta blíže např: The Battle Over Citizen Kane [dokumentární film]. Režie Michael EPSTEIN, Thomas LENNONIS, PBS, 1996.

35 BALL Tevvy, BARTH Rachel, eds. Guide to the Getty Villa. Los Angeles: J. Paul Getty Museum, 2018, s. 15. 36 PROCTER, Ben. William Randolph Hearst. Final Edition, 1911-1951. Oxford: Oxford University Press, 2007, s. 133, pozn. 9. výbava bájného paláce je popsána jako "kolekce všeho možného", tak obrovská, „že to nikdy nebude možné zkatalogizovat či ocenit. Je toho dost pro deset muzeí, kořist světa."

$\mathrm{V}$ závěrečné sekvenci filmu vede skupina sepisovatelů a dohlížitelů rozhovor: "Jakou to všechno má podle Vás cenu, pane Thompsone?" "Miliony, pokud to bude někdo chtit." "No, alespoň že to všechno převezl do Ameriky." V dalším rozhovoru zaznívá: "Co to je?" "Další Venuše", "25.000 dolarü", "To je dost za dámu bez hlavy". Na zmíněnou rozmanitost Hearstovy sbírky, i tu kvalitativní, je poukázáno $\mathrm{v}$ dialogu: "Jedny kamna z pozůstalosti Mary Kaneové, Colorado, cena 2 dolary", "Máme vzít vše, smetí i umělecká díla." "Ten skutečně rád sbíral, cokoli a vše", "Barmský chrám a tři španělské stropy $v$ halách, část skotského zámku, který musí být rozbalen". "Dejte to vše k sobě. Paláce a malby a hračky a všechno."

Připodobnění filmové postavy Charlese Fostera Kanea, ztělesněné samotným Orsonem Wellesem, k Williamu Randolphu Hearstovi způsobilo částečné nepochopení a nedocenění Hearstových sběratelských úspěchů a jeho zhodnocení coby významného stavebníka. ${ }^{34}$ I přesto nelze upřít, že Hearst jako jeden z nejvýznamnějších mecenášů veřejných muzejních sbírek, úzce spjatých s kalifornským prostředím, patři nejen $\mathrm{k}$ nejpozoruhodnějším postavám americké historie, ale má také mnoho společného s evropským kulturním dědictvím. Podobně jako římští císaři, středověcí vladaři i další slavní vojevůdci včele s Napoleonem se i Hearst snažil zajistit si slávu svým „monumentem-muzeem", zhmotňujícím jeho nesmrtelnost. Fenomén budování velkolepých uměleckých sbírek a jejich následné věnování veřejnosti je pro americké prostředí příznačné po celé 20. století, počínaje Zlatým věkem. První velké mecenáše uměleckých sbírek i v průběhu druhé poloviny 20. století následovaly další významné osobnosti. Hearstův hrad společně s jeho obsáhlými sbírkami se stal jedním z ideových vzorů např́iklad pro Jeana Paula Gettyho, který od 50. let 20. století budoval muzeum pro svou uměleckou sbírku v Malibu v Los Angeles, jež byla v roce 1974 rovněž odkázána veřejnosti. ${ }^{35}$

Při společné konverzaci George Bernard Shaw připodobnil Hearstův hrad k dílu Stvořitele, když řekl: „,Bezpochyby, takhle by to postavil Bůh, pokud by měl Tvé peníze."36

\section{Použité zdroje:}

AIDALA, Thomas. Hearst Castle, San Simeon. New York: Hudson Hills Pr., 1981

BALL Tevvy, BARTH Rachel, eds. Guide to the Getty Villa. Los Angeles: J. Paul Getty Museum, 2018

BROWN, Thomas. The Illustrated History of Hearst Castle. Atascadero: Nouveaux Press, 2016

COFFMAN, Taylor. Hearst Castle, The Story of William Randolph Hearst and San Simeon. Santa Barbara: A Sequoia Book - Oak Tree Publications, 1985

DAVIES Marion: The Times We Had: Life with William Randolph Hearst. PFAU Pamela, MARX Kenneth S., eds. New York: Ballantine Books, 1987

GANZ, James A., ed. Jewel City. Art from San Francisco's Panama-Pacific International Exposition. San Francisco: Fine Arts Museum, 2015

HOLMES BOUTELLE, Sara, BARNES, Richard. Julia Morgan, Architect. Abbeville Press, 1995

KASTNER, Victoria. Hearst Castle, the Biography of a Country House. New York: Abrams, 2000

KILZER, Tanja. „La Cuesta Encantada“ Hearst Castle (USA), das "Schloss“ von William Randolph Hearst im spanischen Neokolonialstil im kalifornischen San Simeon. Burgen und Schlösser. Hrsg. und Verl.: Europäisches Burgeninstitut, Einrichtung der Deutschen Burgenvereinigung Braubach, 60. Jahrgang, 2019, Heft 3, s. 164-178.

LEVKOFF, Mary L. Hearst the Collector. Los Angeles: Los Angeles County Museum of Art, 2008

MULVEYOVÁ, Laura. Občan Kane. Citizen Kane. Praha: Casablanca 2009 
NEWCOMB, Rexford. Mediterranean Domestic Architecture for the United States. (Twentieth Century Landmarks in Design, Vol. 9). New York: Acanthus Press, reprint 1999

NEWCOMB, Rexford. Spanish Colonial Architecture in the United States. New York: Augustin Publisher, 1937

PROCTER, Ben. William Randolph Hearst. Final Edition, 1911-1951. Oxford: Oxford University Press, 2007

WADSWORTH, Ginger. Julia Morgan, Architect of Dreams, Minneapolis: Lerner Publication Company, 1990

WILSON, Mark. Julia Morgan: Architect of Beauty, Layton: Gibbs Smith Publisher, 2007

\section{Filmy:}

Občan Kane [Citizen Kane] [film]. Režie Orson WELLES. USA, RKO Pictures, 1941

The Battle Over Citizen Kane [dokumentární film]. Režie Michael EPSTEIN, Thomas LENNONIS, PBS, 1996

\section{Internetové zdroje:}

http://hearstcastle.org/history-behindhearst-castle/ 